\title{
Pharmacological Treatment for Acute Traumatic Musculoskeletal Pain in Athletes
}

\author{
Alessandro de Sire ${ }^{1, *(D)}$, Nicola Marotta ${ }^{1}\left(\mathbb{D}\right.$, Lorenzo Lippi $^{2} \mathbb{D}$, Dalila Scaturro ${ }^{3} \mathbb{D}$, Giacomo Farì ${ }^{4}$, \\ Alfonso Liccardi ${ }^{5}$ (D), Lucrezia Moggio ${ }^{1}$ (D) , Giulia Letizia Mauro ${ }^{3}$, Antonio Ammendolia ${ }^{1}$ (D) \\ and Marco Invernizzi ${ }^{2,6}$ (D)
}

check for updates

Citation: de Sire, A.; Marotta, N.; Lippi, L.; Scaturro, D.; Farì, G.; Liccardi, A.; Moggio, L.; Letizia Mauro, G.; Ammendolia, A.; Invernizzi, M. Pharmacological Treatment for Acute Traumatic Musculoskeletal Pain in Athletes. Medicina 2021, 57, 1208. https:// doi.org/10.3390/medicina57111208

Academic Editor: Jose Antonio de Paz

Received: 21 September 2021

Accepted: 2 November 2021

Published: 5 November 2021

Publisher's Note: MDPI stays neutral with regard to jurisdictional claims in published maps and institutional affiliations.

Copyright: (c) 2021 by the authors. Licensee MDPI, Basel, Switzerland. This article is an open access article distributed under the terms and conditions of the Creative Commons Attribution (CC BY) license (https:/ / creativecommons.org/licenses/by/ $4.0 /)$.
1 Physical and Rehabilitative Medicine, Department of Medical and Surgical Sciences, University of Catanzaro “Magna Graecia”, 88100 Catanzaro, Italy; nicola.marotta@unicz.it (N.M.); lucrezia.moggio@gmail.com (L.M.); ammendolia@unicz.it (A.A.)

2 Physical and Rehabilitative Medicine, Department of Health Sciences, University of Eastern Piedmont, 28100 Novara, Italy; lorenzolippi.mt@gmail.com (L.L.); marco.invernizzi@med.uniupo.it (M.I.)

3 Physical and Rehabilitative Medicine, Department of Surgical, Oncological and Stomatological Disciplines, University of Palermo, 90100 Palermo, Italy; dalila.scaturro@unipa.it (D.S.); giulia.letiziamauro@unipa.it (G.L.M.)

4 Motor and Sports Sciences, Department of Sciences and Biological and Environmental Technologies, Salento University, 73100 Lecce, Italy; dr.giacomofari@gmail.com

5 Department of Biomedical Sciences for Health, University of Milan, 20122 Milan, Italy; alfonsoliccardi91@gmail.com

6 Translational Medicine, Dipartimento Attività Integrate Ricerca e Innovazione (DAIRI), Azienda Ospedaliera SS. Antonio e Biagio e Cesare Arrigo, 15121 Alessandria, Italy

* Correspondence: alessandro.desire@unicz.it; Tel.: +39-0961712819

\begin{abstract}
Pain management is a crucial issue for athletes who train and compete at the highest performance levels. There are still evidence gaps for the use of analgesics for sports injuries despite the growing interest in training and competition settings. However, high-quality research is needed to determine the most appropriate and optimal timing and formulations in non-steroidal anti-inflammatory drug and opioid management, particularly given the strictness of anti-doping regulations. Indeed, the role of pharmacological therapy in reducing acute traumatic pain in athletes should still be addressed to minimize the timing of return to sport. Therefore, the aim of this comprehensive review was to summarize the current evidence about pain management in the setting of acute injury in elite athletes, providing the most informed strategy for pain relief and performance recovery.
\end{abstract}

Keywords: pain management; athletic injuries; trauma; return to sport; sport medicine; rehabilitation

\section{Introduction}

Growing attention has been paid to the promotion of physical activity and a healthy lifestyle over the past decades, with an improved number of initiatives promoting sports in both healthy subjects and patients suffering from various diseases [1-4]. As a result, a constant increase has been registered in the prevalence of both elite and recreational athletes, particularly in youth [5,6]. Apart from the widely noted positive effects of physical activity on cardiovascular and musculoskeletal health [1], the increase in the number of athletes has increased the incidence of sport-related musculoskeletal injuries, with relevant issues on sanitary costs and time lost from sport [7-9].

The International Olympic Committee (IOC) has recently defined sports injuries as new or recurring musculoskeletal complaints occurred during competition or training and requiring medical attention [10]. However, acute sport-related musculoskeletal injuries are characterized by a large heterogeneity in epidemiology and clinical presentation based on the sport performed [11,12]. Additionally, it has been reported that acute traumatic 
musculoskeletal injuries represent the 10-19\% of all acute injuries treated in the emergency department $[13,14]$. Sports-related injuries still represent a critical issue in sports medicine, despite the large attention paid to prevention programs $[15,16]$. To date, the negative effects of pain on training and physical function lead to a psychological and economic burden for athletes and their teams [17,18].

In this situation, an individualized and patient-tailored approach, including pain management, physical therapy, and rehabilitation, has been recommended to manage sports-related musculoskeletal injuries [10,19-23]. In 2016, Ahmadi et al. [24] assessed the pharmacological approach to traumatic injuries, highlighting the need for an age-specific individualized treatment. However, it should be noted that sports athletes usually require a tailored management to enhance the rehabilitation and the return to play (RTP) [24]. Accordingly, Zideman et al. [23] confirmed that a multitarget approach is crucial for elite athletes in terms of pain management. However, the authors included both nonpharmacological and pharmacological approaches, without focusing on acute traumatic injuries [23].

To the best of our knowledge, the role of pharmacological therapy in reducing acute traumatic pain in sportsmen should be addressed to optimize pain management, minimizing the timing of RTP.

Thus, by the present comprehensive narrative review, we aimed to summarize the state of the art about the pharmacological treatment for acute traumatic musculoskeletal pain in athletes, in order to enhance knowledge on this subject, and to guide physicians in the common clinical practice, management, and rehabilitation of these subjects.

\section{Main Acute Traumatic Musculoskeletal Pain in Athletes}

Musculoskeletal injuries represent the most common sports-related injuries [25], though the characteristics of specific sports and the physical stresses related to sports activities significantly affect the prevalence of the different types of injuries [14]. Therefore, an adequate assessment of sport-specific demands is particularly important to guide physicians not only in specific diagnoses but also in the prescription of a multitarget and multimodal therapeutic plan including pain management, sport-specific rehabilitation, and prevention of re-injuries [26].

Conversely, several athletes' characteristics should be taken into consideration to provide a precise diagnosis, including the main risk factors affecting injury risks such as age, gender, and level of play [27-29]. In particular, it has been reported that ankle sprains and knee injuries are more common in women, probably due to higher estrogen levels, higher body fat mass, lower muscle mass, greater flexibility, and a wider pelvis [27,28,30]. At the same time, chronic and overuse injuries are most common in older athletes, given the loss of elasticity and the less effective reparation mechanisms in tendons and muscles [31]. Accordingly, the level of play might significantly affect injury risk due to the number of hours of play per week, and the intensity of training and competitions [32]. Therefore, clinicians should be aware of the potential implications of a patient's characteristics, guiding a precise diagnostic process aimed at supporting a precise diagnosis that represents the starting point for an individualized and tailored pain management.

In these scenarios, acute traumatic musculoskeletal injuries are characterized by a sudden trauma to the tissue, commonly related to a specific identifiable event during the sports activity. Acute sport-related injuries might be classified according to the tissues involved in the injury (e.g., bone, ligament, muscle, tendon, joint,) and the type of injury (e.g., fracture, dislocation, sprain, or strain) [33] (See Figure 1 for further details on ankle injuries as an example). 


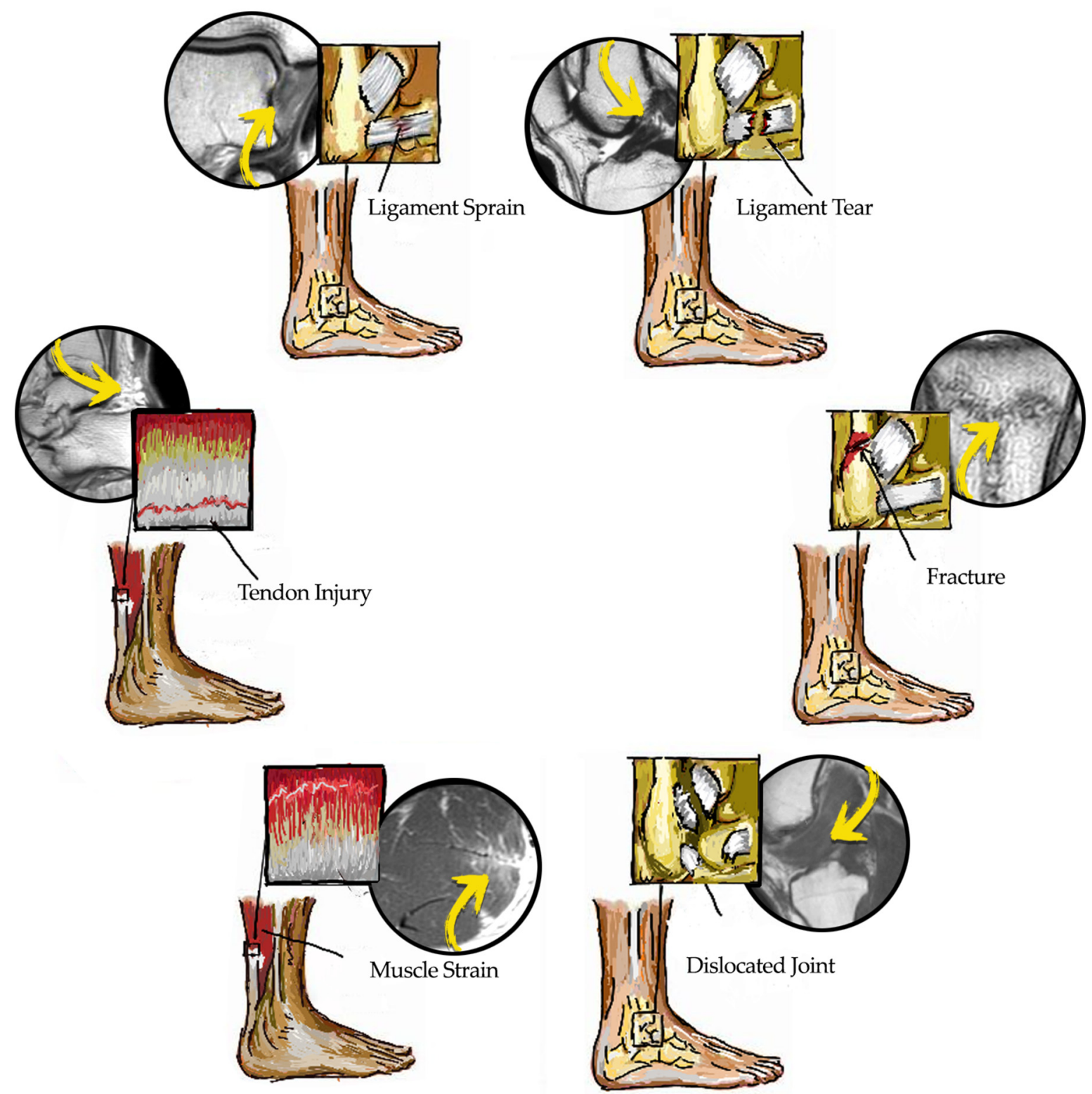

Figure 1. Main sports-related traumatic musculoskeletal injuries (graphical model and magnetic resonance imaging).

In further detail, the main painful sports-related traumatic injuries could include:

- Ankle sprains: These represent very common sports-related musculoskeletal injuries, especially in team sports [34]. An incidence of 3.1 per 1000 ankle sprains per season in elite athletes $[35,36]$ is estimated. Recovery time and type of rehabilitation protocol are structured based on the severity of the injury. Unfortunately, the injury significantly predisposes the athlete to recurrent ankle sprains [37].

- Knee injuries: Anterior cruciate ligament (ACL) injuries are among the most disabling sports-related issues and occur in a range of 29 to 38 per 100,000 athletes [38,39]. However, other structures might be torn or overstretched during a knee sprain, resulting in injuries of posterior cruciate ligament, medial collateral ligament, lateral collateral ligament, or capsular sprain [40]. Nonetheless, meniscus injuries represent $8 \%$ of all seasonal injuries in professional football, since it is a sport characterized by pivoting and cutting movements [41].

- Muscle injuries: Muscle injuries represent one-third of sport-related injuries in soccer players and $92 \%$ of them affect hamstrings, adductors, quadriceps, and calf mus- 
cles [42]. The pathological process can be characterized by direct trauma (muscle contusion) caused by a direct impact on soft tissues [43], or by indirect trauma (contraction-induced injury) due to severe mechanical stress on muscle fibers. In particular, the principal cause of indirect injuries is an excessive eccentric contraction or overstretching of the muscle, frequently related to rapid acceleration or deceleration $[33,44]$. To date, several classifications have been proposed to better characterize these injuries, and treatment and prognosis are based on the following classification [45-47].

- Tendon injuries: the most common acute tendon injury is the tendon rupture, due to an acute traumatic single event that leads to a singular macro-trauma on previously healthy tissue, not involved in chronic inflammation or a degenerative process [48]. The most common tendon involved is the Achilles tendon [49], and male and older athletes seem to be the most affected, reaching an incidence of approximately 40/100,000 persons per year [50]. Despite several approaches being proposed, surgical intervention is the most used in clinical practice, followed by an early functional rehabilitation program with evidence of a significant reduction in risk of recurrence [51].

- Upper limb injuries: Shoulder dislocations represent relatively common sports-related injuries, consisting $3.6 \%$ of all injuries in high school athletes, with an overall rate of 2.04 per 100,000 athletes [52]. They may occur when two or more bones are forced out of their normal position resulting in an abnormal and permanent separation in the joint. The shoulder dislocation represents $54.9 \%$ of dislocation in athletes $[52,53]$. Due to their traumatic etiology, dislocations are more frequent in sports with high risk of falling, such as rugby, hockey, and wrestling [54]. On the other hand, in the elite athlete, rotator cuff injuries can occur with acute episodes of direct contact trauma, a fall on an outstretched arm, and represent almost half (47\%) of overall shoulder injuries per single season [55]. Medial ulnar collateral ligament (MUCL) injuries are described primarily as chronic progressive injuries but are underestimated as acute lesions in young athletes who play overhead sports [56].

- Fractures: Sport-related fractures, 5-10\% of injuries in athletes, are very painful conditions, commonly resulting from a sudden trauma especially in contact sports or in sports with high risk of falls $[57,58]$. In this context, pain management plays a key role and requires specific strategies depending on the site of the fracture [59].

Therefore, alongside an adequate pain management, an optimization of the functional recovery and a safe RTP should be taken into consideration for athletes with sports-related injuries.

\section{Analgesic Pharmacological Approach}

The analgesic pharmacological approach historically represents the cornerstone of pain management for acute traumatic musculoskeletal injuries [25,60]. However, it should be noted that the pharmacological approach should be considered just one component in an integrated and multidisciplinary approach aimed at reducing physical impairment and optimizing functional recovery and RTP [61-64]. The IOC Consensus Statement [10] recommended that analgesic drug prescription should be performed targeting the lowest effective dose for the shortest period. Therefore, particular attention should be paid to minimize adverse risks and to achieve pain relief; furthermore, in the case of ineffective or intolerance to treatment, the drug should be discontinued [10].

Tissue location, type of injury, and pain severity significantly influence the treatment approach [65]. In this context, a recent review [23] underlined those minor injuries that might often be treated by non-opioid analgesic medication and non-pharmacological treatment; however, the effectiveness of this approach in different pathologies has not been deeply studied. In minor injuries, when same-day RTP is considered, oral or local analgesic drugs are routinely used according to the scientific literature that showed a positive effect $[25,66-75]$. 
Furthermore, when prescribing analgesic drugs, it is necessary to carefully consider different mechanisms of action and safety, as different pharmacological agents may be associated with different side effects [76]. According to the World Health Organization (WHO) pain ladder [77], non-narcotic analgesics may be used to manage mild to moderate pain. Nevertheless, the combination with narcotic analgesics may be performed to manage severe pain to obtain synergic effects [76]. To date, several options are currently available in the pharmacological non-invasive approach in acute traumatic injury, including paracetamol [78-81], non-steroidal anti-inflammatory drugs (NSAIDs) [80,82-85], and opioids [79-81,86-88].

- Paracetamol: one of the most common drugs routinely used for mild and moderate pain alone or combined with other pharmacological and non-pharmacological interventions [89]. In accordance with the WHO Pain Ladder Recommendations [89], it should be considered as a first-line treatment in mild pain. Furthermore, the safety of paracetamol at up to $3 \mathrm{~g}$ per day is well documented with studies reporting adverse effects compared to placebo [90,91]. In addition, studies comparing paracetamol to NSAID for treating pain after acute sport-related injuries did not report significant differences in term of effectiveness [92]. Similarly, a combination of paracetamol and NSAIDs might be more effective in pain relief, even if side effects might be more frequent [93].

- NSAIDs: This pharmacologic treatment is highly supported by the literature for pain management $[80,82-85,94-96]$; however, specific interventions including the exact time, dose, and duration of specific NSAIDs targeting a specific acute traumatic injury are still lacking. Apart from these limitations, NSAIDs are currently the most prescribed drugs in sport-related injuries, but another crucial issue is represented by the administration modalities.

In this context, a recent Cochrane review showed that topical diclofenac and ketoprofen could be effective in pain relief of acute sprains and strains [97]. Moreover, the intradermal absorption significantly minimizes the risk for adverse events, and the approximate benefit of $50 \%$ of pain relief after 1 week makes this treatment suitable as a first-line treatment for minor acute injuries $[97,98]$. To date, ketorolac is the most supported NSAID in acute pain management, as confirmed by a recent meta-analysis [99] highlighting the role of ketorolac in severe pain relief and an adequate safety profile if dismissed in 5 days. On the other hand, no randomized controlled trials (RCTs) have been performed supporting the ketorolac effects when compared to different NSAIDs. A recent report underlined a potential increase in the risk of post-traumatic hemorrhage and acute traumatic injuries, underlining that NSAIDs should be carefully administered in these subjects [100]. NSAIDs should be avoided in the first $72 \mathrm{~h}$ from brain concussion given the increased risk of bleeding [101]. In accordance, since inflammation has a crucial role in the first processes at the basis of tissue healing in the skeletal muscle system [68,102-105], the anti-inflammatory pharmacological approach has been recently questioned [68]. Moreover, NSAIDs mediate their pharmacological effects by the inhibition of prostaglandin synthesis in the COX pathway; therefore, a careful prescription of these drugs should consider the evidence highlighting the potential negative effects in bone, muscle, ligament, and tendon healing $[68,102-105]$. However, no studies assessed the long-term effects of NSAIDs in athlete global health, tissue overload on the kinetic chain continuum, injury recurrence, or complications related to pain relief effects [23].

- Opioids: These drugs should be prescribed in sports for major traumas that could be related to a high risk of bleeding and severe pain. Indeed, in these cases, NSAIDs did not represent a suitable option according to the WHO pain ladder recommendations [89]. In this context, the NICE guideline for major trauma in adults [106] supported the use of intravenous morphine as the first-line analgesic in the hospital or pre-hospital setting to achieve adequate pain relief without affecting blood coagulation. The IOC recommended that opioids should be considered for athletes only in case of severe 
pain with the initial prescription not exceeding 5 days [107]. However, longer prescriptions have been reported despite the critical issue of risks of opioid dependence or addiction.

Rehabilitation might play a crucial role as a synergistic approach with the pharmacological therapy to reduce acute traumatic musculoskeletal pain. In this situation, instrumental physical therapies might be considered a complementary approach in both acute and chronic pain $[108,109]$. In addition, optimal pain management is a cornerstone of a proper rehabilitation plan, thus avoiding the psychological burden related to musculoskeletal pain and minimizing the fear of movement that might significantly affect the time of RTP and reinjury risk [110-112].

Moreover, treatment reducing deconditioning and enhancing physical performance should be considered even in the early stages of acute traumas [113]. Thus, the term "rehabilitation pharmacotherapy" has been recently introduced to characterize a specific pharmacological approach aimed at achieving the highest physical performance, physical function, and quality of life; a rehabilitative intervention that aims to influence the therapeutic approach, calming the multi-drug management [114]. Despite the studies supporting this approach mainly focused on older people [114,115], "rehabilitation pharmacotherapy" should be seriously considered in the pain management of sports athletes. Therefore, the pharmacological approach should not interfere with rehabilitation and RTP [114,115]. However, more evidence is needed to fully support this approach in athletes.

\section{Invasive Pain Management: What Role for Infiltrations in Athletes?}

Mini-invasive procedures are commonly used in clinical practice for chronic pain $[109,116-118]$, but they are still not adequately investigated and performed for acute traumatic sports-related injuries $[72,119,120]$. In this situation, local anesthetic injections are frequently performed to ensure an anticipated or immediate RTP in elite athletes [121]. Drakos et al. [121] reported the effects of ultrasound-guided local anesthetic injections within $1 \mathrm{~h}$ of competition in patients suffering from muscle injuries and ankle sprains, demonstrating a high safety profile, and supporting their role in anticipated RTP.

To date, there is a lack of evidence on the impact of local anesthetic injections in acute sports-related injuries [122]. It is crucial that the type of the treatment should depend on the site of the injury [123-125]. However, the majority of evidence supporting corticosteroid injections for musculoskeletal pain involves non-athletes [126-130]. In addition, the corticosteroid effects in pain relief in acute sport-related injury are not fully supported by the current literature due to the potential interaction in physiological molecular pathways underpinning tissue healing [122,131,132].

Hyaluronic acid (HA) injection, notably, represents an effective and safe option in the treatment of articular pain in athletes, with recent evidence suggesting a potential effect in accelerating RTP [122,133]. To date, the Osteoarthritis Research Society International classification [134] reported that HA injections might be a recommended mini-invasive procedure to treat even early osteoarthritis in older athletes [122].

On the other hand, in young athletes, HA injection might have a role in multifactorial pain syndromes involving articular damage or cartilage involvement. In particular, the recent review by da Costa [135] supported HA injection in a multimodal treatment of patellar chondropathy. Moreover, given the lack of doping issues [136], HA injection represent a feasible and safe therapy for sport-related injuries in elite athletes [122,133]. However, in severely injured athletes, who have no benefit from conventional therapies, mini-invasive procedures should be taken into consideration [131,132].

Another technique that might be performed for acute pain in athletes is regional anesthesia, a procedure strictly linked to the type of injury; in particular, forearm nerve blocks or axillary blocks might be effective in pain management of hand and forearm fractures $[137,138]$. In addition, distal radius fracture management during reduction might involve hematoma block (achieving good results in pain relief) [58]. Similarly, sciatic nerve 
blocks, adductor canal nerve blocks, fascia iliaca nerve blocks, and femoral nerve blocks have been demonstrated to be effective in specific pathologies to achieve adequate analgesia and reduce opioid medications after acute traumatic injuries requiring surgery [58,139-142]. Despite the promising effects of nerve block injections, some authors reported that regional anesthesia might mask compartment syndrome onset, therefore these procedures should be carefully performed [58].

However, it should be noted that, though nerve block might improve pain management and reduce oral medication [143-145], multimodal analgesia has been strongly recommended [146]. Therefore, mini-invasive procedures should be considered in a combination of pharmacological strategies to potentially reduce the side effects of monotherapy and improve pain management in acute injuries [146].

Moreover, infiltrations should always be framed within a comprehensive, multidisciplinary approach, including not only other pharmacological approaches but also nonpharmacological ones. Indeed, physical therapy might play a key role in pain control with growing evidence supporting its effects if combined with mini-invasive rehabilitative approaches $[109,112,117,147]$. To date, several reports suggested that physical activity might modulate pain perception modulating central nervous system excitability, and improving psychological constructs associated with pain $[148,149]$.

On the other hand, rehabilitation might have several synergic effects with miniinvasive procedures, especially in athletes [150]. In more detail, pain control during rehabilitation might improve muscle tension, encourage realignment of the body, and prevent the fear of movement that affects functional outcomes and reinjury risk, potentially enhancing rapid recovery and RTP [151-153]. At the same time, physical therapy might induce pain relief by decreasing inflammation, increasing mobility, and decreasing overall pain levels with a high safety profile $[112,154,155]$. Moreover, considering the crucial issue of RTP in athletes, any therapeutic pathway should be integrated with treatment that enhances physical conditioning, including physical therapy, and retraining exercise $[156,157]$.

In conclusion, rehabilitation represents a suitable therapeutic option in multimodal pain management (including infiltrations) for the management of musculoskeletal pain in athletes. However, these mini-invasive approaches should be safe, appropriate, and patient-tailored to optimize functional recovery and RTP in a comprehensive multimodal rehabilitation plan.

\section{Return-to-Play after Trauma}

RTP is crucial for elite athletes after an acute trauma, given the economic and competitive entanglements associated with absence for professional players [158]. Injury management should include proper pain management as a key step of a tailored intervention to enhance the RTP program [159]. Therefore, an evidence-based epidemiological report might guide physicians in the prognostic assessment to approach concerns from players, coaches, managers, media, and agents regarding RTP [160].

RTP may change according to the anatomical site and severity of the acute traumatic pain:

- Ankle sprains: Physicians should evaluate specific movements to determine appropriate RTP following an ankle sprain. Athletes should use a drop test to estimate the sportive gesture evaluation, considering muscle strength, proprioceptive balance, and joint range of motion [161]. In summary, appropriate RTP must be based on objective and scalable assessments that inform professionals about the future risk of injury. The experts' consensus indicates that RTP must focus on the sport gesture that the athlete requires in practice [161]. Unfortunately, due to the lack of evidence, each practitioner needs to establish an objective threshold for assessing a tailored RTP [162].

- Knee injuries: About half of athletes return to competitive sport after primary ACL reconstruction [163]. Regardless of treatment, the RTP rate is affected by factors including specific sport demands and regional differences. RTP rates are lower after revision 
ACL reconstruction than after primary surgery [164]. Interestingly, the duration of RTP after an ACL reconstruction has a high variability in male professional football players, but, independent of this time, only a minority of athletes return to their preinjury level 1 year after surgery [165]. However, the mean lay-off time in professional football for all Medial Collateral Ligament (MCL) injuries is $23 \pm 23$ days [166] given that MCL injuries can be managed conservatively, though grade III MCL injuries or involvement of the deep MCL and/or the posterior oblique ligament are associated with longer recovery time. Lastly, athletes requiring lateral meniscus treatment have longer recovery times and lower RTP rates than athletes who require medial meniscus treatment [167].

- Muscle injuries: Acute hamstring injury is the most frequent non-contact muscle injury in sports involving high-speed running, with a consistently high incidence and high reinjury risk $[42,168,169]$. Given the high heterogeneity of injury location and severity, time to RTP after acute hamstring injuries varies substantially from an average of 11.3 days to 50 weeks [170]. Among professional football players, the mean lay-off time was shown to be around 20 days [167]. On the other hand, total proximal hamstring ruptures might represent the highest grade of muscle injury, requiring surgery; therefore, RTP duration sensibly increases and is generally allowed after 6-9 months [171]. Intriguingly, there is currently no strong evidence that Magnetic Resonance Imaging (MRI) could be a predictive factor for RTP [172,173]. However, RTP is not a major issue in acute hamstring injuries because close to $100 \%$ of athletes RTP after an injury [174].

- Tendon injuries: The Achilles tendon is one of the most injured tendons in athletes involved in running and jumping activities [174]. It has been estimated that between 10 and $86 \%$ of athletes have RTP after 12 weeks of treatment for Achilles tendinopathy. However, up to half of athletes have a recurrence of Achilles tendinopathy after RTP [174]. After Achilles tendon rupture, 29-87\% of athletes return to their pre-injury level [175]. Nevertheless, rehabilitation exercises are the cornerstone of RTP in Achilles tendinopathy, given that those who follow a standardized load progression have fewer incidences of recurrence compared with those who do not follow a progressive loading program [176]. Apart from these findings, permanent deficits in calf muscle strength and tendon elongation can be very common after Achilles tendon rupture [177]. Therefore, it is particularly important that athletes with Achilles tendinopathy undergo a full progressive loading program prior to clearance to RTP [176]. On the other hand, there are no milestone-based criteria for RTP following Achilles tendon rupture. The time-based criteria for non-contact sports are resumption from 16 weeks following injury and for contact sports from 20 weeks after injury [178].

- Upper limb injuries: Shoulder dislocations represent the most common site of dislocation in athletes. Nevertheless, little evidence exists regarding the physical RTP criteria of the shoulder after injury [179]. In more detail, nonoperatively treated shoulder instabilities that sustained shoulder subluxations returned after an average of 3.6 weeks, compared with 7.6 weeks in those who sustained a shoulder dislocation [179]. Players experiencing shoulder dislocations were found to miss more time before RTP and were more likely to undergo surgical intervention compared with those who experienced a subluxation [180]. A recent review [181] demonstrated no overall difference in the rate of RTP or patient-reported outcomes following arthroscopic Bankart repair, the Latarjet procedure, and open stabilization [182]. Return to the same level of play after surgical repair of full-thickness tears in professional overhead athletes has been unpredictable and often this kind of injury is career-ending; arthroscopic repair of full-thickness tears in professional baseball players allowed 83\% to return to play, but few with pre-injury levels of competition [55]. Regarding MCUL, it is well known that operative treatment represents the gold standard for professional players, but, to date, there is no consensus on which approach (i.e., conservative or surgical) represents 
the best choice for high-performance-demand athletes given the poorly predictable RTP [56].

- Fractures: Sports-related fractures may have critical implications for athletes. Fracture management tends toward preserving soft tissue, which is critical for an early recovery in the athletic population $[58,183]$. Given the breadth of circumstances faced during athletic activity, there is no patterned algorithm for defining a player's readiness to RTP after a fracture. Nevertheless, an athlete should be pain-free, neurologically unimpaired, and without deficits of strength or range of motion before returning to sport $[184,185]$.

\section{Antidoping Issues in the Pain Management of Athletes}

Pain management has constantly influenced athletic conditions, thus making necessary the publication of a prohibited substances list by the World Anti-Doping Agency (WADA) [186].

In this context, doping indicates the presence, use, possession, or trafficking of a prohibited substance. Evidence suggests that currently banned narcotic analgesics (opioids) and cannabinoids are not ergogenic but ergolytic [84,186]. Indeed, both can be prescribed by a physician for pain control, but both can be obtained illegally and carry potentially serious health risks, including addiction.

In contrast, the most used analgesics, including non-steroidal anti-inflammatory drugs, acetaminophen, local anesthetics, and tramadol are not forbidden according to the WADA list of prohibited substances $[84,186]$. However, potential ergogenic effects of NSAIDs in sports performance have been recently reported, and, unfortunately, a significant difference between the use of NSAIDs in-competition vs. out-of-competition has been demonstrated, probably related to the postulated effects in improving physical performance [186-191]. Interestingly, performance enhancement seems to be related to the widely noted antalgic effect, which might improve exercise-induced pain level tolerance with consequent positive effects in sports performance [190]. Despite these considerations, the ergogenic effects of NSAIDs have not been supported by strong evidence and these molecules are still not considered forbidden [186].

Moreover, one of the most used methods to control pain is the injection of a local anesthetic, which raises little controversy in sport compared to opiate management, a currently contentious topic perhaps given the epidemic of opiate abuse in some regions of the world [190]. Indeed, although tramadol is not on the list, it may sometimes be abused, such as in cycling [191]. There is a solid argument that all opioids and cannabinoids should be available to the practitioner, but with a remarkably close window for managing these substances in elite competitors [192,193].

\section{Conclusions and Future Perspectives}

In this comprehensive review, we summarized the state-of-the-art in pharmacological intervention efficacy on the pain management of acute sport-related injuries in athletes. Moreover, we highlighted the need for an effective assessment and management of musculoskeletal disorders to obtain a prompt RTP. Intriguingly, there is still a large gap of knowledge in drug-induced pain relief in athletes in terms of kinematic and physical performance.

However, the optimal strategy to manage sport-related injuries should include not only pharmacological interventions but also tailored exercise prescription and load management and rehabilitation. These interventions should be performed by medical, sports science, and technical staff to provide the most effective management of sport-related acute injuries.

To date, evidence about the impact of pharmacological approaches on acute traumatic injuries in terms of kinematic outcomes, RTP, and long-term well-being of athletes is far from being fully established. Therefore, further high-quality studies (both systematic reviews and RCTs) focusing on the most effective rehabilitative and pharmacological interventions to treat acute sport-related injuries are warranted. This could provide evidence to 
guide physicians in the comprehensive clinical and rehabilitative management of acute traumatic sports-related injuries.

Author Contributions: Study design and conceptualization, A.d.S. and M.I.; literature searching, A.d.S., N.M. and L.L.; data synthesis and interpretation, A.d.S., N.M. and L.L.; manuscript drafting, A.d.S., N.M. and L.L.; critical revision, M.I.; visualization, N.M., L.L., D.S., G.F., A.L., L.M., G.L.M. and A.A.; study supervision, A.d.S. and M.I.; study submission, A.d.S. All authors have read and agreed to the published version of the manuscript.

Funding: This research received no external funding.

Institutional Review Board Statement: Not applicable.

Informed Consent Statement: Not applicable.

Data Availability Statement: Not applicable.

Conflicts of Interest: The authors declare no conflict of interest.

\section{References}

1. Warburton, D.E.; Nicol, C.W.; Bredin, S.S. Health benefits of physical activity: The evidence. CMAJ 2006, 174, 801-809. [CrossRef]

2. de Sire, A.; Marotta, N.; Marinaro, C.; Curci, C.; Invernizzi, M.; Ammendolia, A. Role of Physical Exercise and Nutraceuticals in Modulating Molecular Pathways of Osteoarthritis. Int. J. Mol. Sci. 2021, 22, 5722. [CrossRef] [PubMed]

3. Farì, G.; Di Paolo, S.; Ungaro, D.; Luperto, G.; Farì, E.; Latino, F. The Impact of COVID-19 on Sport and Daily Activities in an Italian Cohort of Football School Children. Int. J. Athl. Ther. Train. 2021, 26, 1-5. [CrossRef]

4. Notarnicola, A.; Covelli, I.; Maccagnano, G.; Marvulli, R.; Mastromauro, L.; Ianieri, G.; Boodhoo, S.; Turitto, A.; Petruzzella, L.; Farì, G.; et al. Extracorporeal shockwave therapy on muscle tissue: The effects on healthy athletes. J. Biol. Regul. Homeost. Agents 2018, 32, 185-193. [PubMed]

5. Carder, S.L.; Giusti, N.E.; Vopat, L.M.; Tarakemeh, A.; Baker, J.; Vopat, B.G.; Mulcahey, M.K. The Concept of Sport Sampling Versus Sport Specialization: Preventing Youth Athlete Injury: A Systematic Review and Meta-analysis. Am. J. Sports Med. 2020, 48, 2850-2857. [CrossRef]

6. National Federation of State High School Associations. 2008-09 High School Athletics Participation Survey. Available online: http:/ / www.nfhs.org/content.aspx?id=3282\&linkidentifier=id\&itemid=3282 (accessed on 11 August 2010).

7. Centers for Disease Control and Prevention. Nonfatal traumatic brain injuries related to sports and recreation activities among persons aged \#19 years-United States, 2001-2009. MMWR 2011, 60, 1337-1342.

8. Emery, C.A.; Pasanen, K. Current trends in sport injury prevention. Best Pract. Res. Clin. Rheumatol. 2019, 33, 3-15. [CrossRef]

9. Lystad, R.P.; Curtis, K.; Browne, G.J.; Mitchell, R.J. Incidence, costs, and temporal trends of sports injury-related hospitalisations in Australian children over a 10-year period: A nationwide population-based cohort study. J. Sci. Med. Sport 2019, 22, 175-180. [CrossRef]

10. Hainline, B.; Derman, W.; Vernec, A.; Budgett, R.; Deie, M.; Dvořák, J.; Harle, C.; Herring, S.A.; McNamee, M.; Meeuwisse, W.; et al. International Olympic Committee consensus statement on pain management in elite athletes. Br. J. Sports Med. 2017, 51, 1245-1258. [CrossRef]

11. Szymski, D.; Achenbach, L.; Krutsch, V.; Alt, V.; Meffert, R.; Krutsch, W.; Fehske, K. Injury epidemiology in men's professional team sports: Is media analysis helpful? Arch. Orthop. Trauma Surg. 2021, 141, 655-661. [CrossRef]

12. Farì, G.; Notarnicola, A.; Di Paolo, S.; Covelli, I.; Moretti, B. Epidemiology of injuries in water board sports: Trauma versus overuse injury. J. Sports Med. Phys. Fit. 2021, 61, 707-711. [CrossRef]

13. Bahr, R.; Krosshaug, T. Understanding injury mechanisms: A key component of preventing injuries in sport. Br. J. Sports Med. 2005, 39, 324-329. [CrossRef] [PubMed]

14. Fuller, C.W. Managing the risk of injury in sport. Clin. J. Sport Med. 2007, 17, 182-187. [CrossRef] [PubMed]

15. Stracciolini, A.; Sugimoto, D.; Howell, D.R. Injury Prevention in Youth Sports. Pediatr. Ann. 2017, 46, e99-e105. [CrossRef]

16. McCarthy, M.M.; Hannafin, J.A. The mature athlete: Aging tendon and ligament. Sports Health 2014, 6, 41-48. [CrossRef]

17. Parfitt, G.; Rose, E.; Burgess, W.M. The psychological and physiological responses of sedentary individuals to prescribed and preferred intensity exercise. Br. J. Health Psychol. 2006, 11, 39-53. [CrossRef]

18. Öztürk, S.; Kılıç, D. What is the economic burden of sports injuries? Eklem. Hastalik. Cerrahisi. 2013, 24, 108-111. [CrossRef]

19. El-Tallawy, S.N.; Nalamasu, R.; Salem, G.I.; LeQuang, J.A.K.; Pergolizzi, J.V.; Christo, P.J. Management of Musculoskeletal Pain: An Update with Emphasis on Chronic Musculoskeletal Pain. Pain Ther. 2021, 10, 181-209. [CrossRef]

20. Bernetti, A.; Agostini, F.; de Sire, A.; Mangone, M.; Tognolo, L.; Di Cesare, A.; Ruiu, P.; Paolucci, T.; Invernizzi, M.; Paoloni, M. Neuropathic Pain and Rehabilitation: A Systematic Review of International Guidelines. Diagnostics 2021, 11, 74. [CrossRef]

21. Haraldsdottir, K.; Watson, A.M. Psychosocial Impacts of Sports-related Injuries in Adolescent Athletes. Curr. Sports Med. Rep. 2021, 20, 104-108. [CrossRef] 
22. Dingenen, B.; Gokeler, A. Optimization of the Return-to-Sport Paradigm After Anterior Cruciate Ligament Reconstruction: A Critical Step Back to Move Forward. Sports Med. 2017, 47, 1487-1500. [CrossRef]

23. Zideman, D.A.; Derman, W.; Hainline, B.; Moseley, G.L.; Orchard, J.; Pluim, B.M.; Siebert, C.H.; Turner, J.A. Management of Pain in Elite Athletes: Identified Gaps in Knowledge and Future Research Directions. Clin. J. Sport Med. 2018, 28, 485-489. [CrossRef]

24. Ahmadi, A.; Bazargan-Hejazi, S.; Heidari Zadie, Z.; Euasobhon, P.; Ketumarn, P.; Karbasfrushan, A.; Amini-Saman, J.; Mohammadi, R. Pain management in trauma: A review study. J. Inj. Violence Res. 2016, 8, 89-98. [CrossRef] [PubMed]

25. Feucht, C.L.; Patel, D.R. Analgesics and anti-inflammatory medications in sports: Use and abuse. Pediatr. Clin. N. Am. 2010, 57, 751-774. [CrossRef]

26. Aicale, R.; Tarantino, D.; Maffulli, N. Overuse injuries in sport: A comprehensive overview. J. Orthop. Surg. Res. 2018, 13, 309. [CrossRef]

27. Lam, K.C.; Valier, A.R.S.; McLeod, T.C.V. Injury and treatment characteristics of sport-specific injuries sustained in interscholastic athletics: A report from the athletic training practice-based research network. Sports Health 2015, 7, 67-74. [CrossRef] [PubMed]

28. Farì, G.; Fischetti, F.; Zonno, A.; Marra, F.; Maglie, A.; Bianchi, F.P.; Messina, G.; Ranieri, M.; Megna, M. Musculoskeletal Pain in Gymnasts: A Retrospective Analysis on a Cohort of Professional Athletes. Int. J. Environ. Res. Public Health 2021, 18, 5460. [CrossRef] [PubMed]

29. Bahr, R.; Clarsen, B.; Derman, W.; Dvorak, J.; Emery, C.A.; Finch, C.F.; Hägglund, M.; Junge, A.; Kemp, S.; Khan, K.M.; et al. International Olympic Committee consensus statement: Methods for recording and reporting of epidemiological data on injury and illness in sport 2020 (including STROBE Extension for Sport Injury and Illness Surveillance (STROBE-SIIS)). Br. J. Sports Med. 2020, 54, 372-389. [CrossRef]

30. Lin, C.Y.; Casey, E.; Herman, D.C.; Katz, N.; Tenforde, A.S. Sex Differences in Common Sports Injuries. PMR 2018, 10, 1073-1082. [CrossRef]

31. Kammerlander, C.; Braito, M.; Kates, S.; Jeske, C.; Roth, T.; Blauth, M.; Dallapozza, C. The epidemiology of sports-related injuries in older adults: A central European epidemiologic study. Aging Clin. Exp. Res. 2012, 24, 448-454. [CrossRef]

32. Luiggi, M.; Griffet, J. Sport injury prevalence and risk by level of play and sports played among a representative population of French adolescents. A school-based study. Rev. D'epidemiologie Sante Publique 2019, 67, 383-391. [CrossRef]

33. Brukner, P. Brukner \& Khan's Clinical Sports Medicine. Physiother. Can. 2014, 66, 109-110. [CrossRef]

34. Fong, D.T.; Hong, Y.; Chan, L.K.; Yung, P.S.; Chan, K.M. A systematic review on ankle injury and ankle sprain in sports. Sports Med. 2007, 37, 73-94. [CrossRef]

35. Shah, S.; Thomas, A.C.; Noone, J.M.; Blanchette, C.M.; Wikstrom, E.A. Incidence and cost of ankle sprains in United States emergency departments. Sports Health 2016, 8, 547-552. [CrossRef]

36. Whalan, M.; Lovell, R.; McCunn, R.; Sampson, J.A. The incidence and burden of time loss injury in Australian men ' s sub-elite football (soccer): A single season prospective cohort study. J. Sci. Med. Sport 2019, 22, 42-47. [CrossRef] [PubMed]

37. Ammendolia, A.; Iona, T.; Scarfone, R. Therapy and recurrence prevention of the ankle sprain in elite soccer players. Gazz. Med. Ital. Arch. Sci. Med. 2016, 175, 23-26.

38. Arendt, E.; Dick, R. Knee injury patterns among men and women in collegiate basketball and soccer: NCAA data and review of literature. Am. J. Sports Med. 1995, 23, 694-701. [CrossRef] [PubMed]

39. Hootman, J.M.; Dick, R.; Agel, J. Epidemiology of collegiate injuries for 15 sports: Summary and recommendations for injury prevention initiatives. J. Athl. Train. 2007, 42, 311-319. [PubMed]

40. Clifton, D.R.; Onate, J.A.; Schussler, E.; Djoko, A.; Dompier, T.P.; Kerr, Z.Y. Epidemiology of Knee Sprains in Youth, High School, and Collegiate American Football Players. J. Athl. Train. 2017, 52, 464-473. [CrossRef] [PubMed]

41. Vaishya, R.; Kambhampati, S.B.S.; Vaish, A. Meniscal Injuries in the Olympic and Elite Athletes. Indian J. Orthop. 2020, 54, 281-293. [CrossRef]

42. Ekstrand, J.; Hagglund, M.; Walden, M. Epidemiology of muscle injuries in professional football (soccer). Am. J. Sports Med. 2011, 39, 1226-1232. [CrossRef]

43. Beiner, J.M.; Jokl, P. Muscle contusion injuries: Current treatment options. J. Am. Acad. Orthop. Surg. 2001, 9, 227-237. [CrossRef]

44. Hody, S.; Croisier, J.L.; Bury, T.; Rogister, B.; Leprince, P. Eccentric Muscle Contractions: Risks and Benefits. Front. Physiol. 2019, 10, 536. [CrossRef]

45. Pollock, N.; James, S.L.; Lee, J.C.; Chakraverty, R. British athletics muscle injury classification: A new grading system. Br. J. Sports Med. 2014, 48, 1347-1351. [CrossRef]

46. Mueller-Wohlfahrt, H.W.; Haensel, L.; Mithoefer, K.; Ekstrand, J.; English, B.; McNally, S.; Orchard, J.; van Dijk, C.N.; Kerkhoffs, G.M.; Schamasch, P.; et al. Terminology and classification of muscle injuries in sport: The Munich consensus statement. Br. J. Sports Med. 2013, 47, 342-350. [CrossRef]

47. Hamilton, B.; Valle, X.; Rodas, G.; Til, L.; Grive, R.P.; Rincon, J.A.; Tol, J.L. Classification and grading of muscle injuries: A narrative review. Br. J. Sports Med. 2015, 49, 306. [CrossRef]

48. Dakin, S.G.; Newton, J.; Martinez, F.O.; Hedley, R.; Gwilym, S.; Jones, N.; Reid, H.A.B.; Wood, S.; Wells, G.; Appleton, L.; et al. Chronic inflammation is a feature of Achilles tendinopathy and rupture. Br. J. Sports Med. 2018, 52, 359-367. [CrossRef]

49. Mattila, V.M.; Huttunen, T.T.; Haapasalo, H.; Sillanpää, P.; Malmivaara, A.; Pihlajamäki, H. Declining incidence of surgery for Achilles tendon rupture follows publication of major RCTs: Evidence-influenced change evident using the Finnish registry study. Br. J. Sports Med. 2015, 49, 1084-1086. [CrossRef] 
50. Chiodo, C.P.; Glazebrook, M.; Bluman, E.M.; Cohen, B.E.; Femino, J.E.; Giza, E.; Watters, W.C., III; Goldberg, M.J.; Keith, M.; Haralson, R.H., III; et al. American Academy of Orthopaedic Surgeons. Diagnosis and treatment of acute Achilles tendon rupture. J. Am. Acad. Orthop. Surg. 2010, 18, 503-510. [CrossRef]

51. Caldwell, J.E.; Vosseller, J.T. Maximizing Return to Sports After Achilles Tendon Rupture in Athletes. Foot Ankle Clin. 2019, 24, 439-445. [CrossRef]

52. Kerr, Z.Y.; Collins, C.L.; Comstock, D. Epidemiology of dislocations/separations among US high school athletes. Inj. Prev. 2011, 16 (Suppl. 1), A255-A256.

53. Kerr, Z.Y.; Collins, C.L.; Pommering, T.L.; Fields, S.K.; Comstock, R.D. Dislocation/separation injuries among US high school athletes in 9 selected sports: 2005-2009. Clin. J. Sport Med. 2011, 21, 101-108. [CrossRef]

54. Owens, B.D.; Agel, J.; Mountcastle, S.B.; Cameron, K.L.; Nelson, B.J. Incidence of glenohumeral instability in collegiate athletics. Am. J. Sports Med. 2009, 37, 1750-1754. [CrossRef]

55. Weiss, L.J.; Wang, D.; Hendel, M.; Buzzerio, P.; Rodeo, S.A. Management of Rotator Cuff Injuries in the Elite Athlete. Curr. Rev. Musculoskelet. Med. 2018, 11, 102-112. [CrossRef]

56. Biz, C.; Crimì, A.; Belluzzi, E.; Maschio, N.; Baracco, R.; Volpin, A.; Ruggieri, P. Conservative Versus Surgical Management of Elbow Medial Ulnar Collateral Ligament Injury: A Systematic Review. Orthop. Surg. 2019, 11, 974-984. [CrossRef]

57. Court-Brown, C.M.; Wood, A.M.; Aitken, S. The epidemiology of acute sports-related fractures in adults. Injury 2008, 39, 1365-1372. [CrossRef]

58. Elsevier, H.; Cannada, L.K. Management of Pain Associated with Fractures. Curr. Osteoporos. Rep. 2020, 18, 130-137. [CrossRef]

59. Horn, R.; Kramer, J. Postoperative Pain Control. In StatPearls; StatPearls Publishing: Treasure Island, FL, USA, 2021.

60. Ziltener, J.L.; Leal, S.; Fournier, P.E. Non-steroidal anti-inflammatory drugs for athletes: An update. Ann. Phys. Rehabil. Med. 2010, 53, 278-282. [CrossRef]

61. de Sire, A.; Demeco, A.; Marotta, N.; Moggio, L.; Palumbo, A.; Iona, T.; Ammendolia, A. Anterior Cruciate Ligament Injury Prevention Exercises: Could a Neuromuscular Warm-Up Improve Muscle Pre-Activation before a Soccer Game? A Proof-ofPrinciple Study on Professional Football Players. Appl. Sci. 2021, 11, 4958. [CrossRef]

62. Sokol, R.G.; Pines, R.; Chew, A. Multidisciplinary Approach for Managing Complex Pain and Addiction in Primary Care: A Qualitative Study. Ann. Fam. Med. 2021, 19, 224-231. [CrossRef]

63. Hermann, M.; Ruschitzka, F. Cardiovascular risk of cyclooxygenase-2 inhibitors and raditional non-steroidal anti-inflammatory drugs. Ann. Med. 2007, 39, 18-27. [CrossRef] [PubMed]

64. Pepine, C.J.; Gurbel, P.A. Cardiovascular safety of NSAIDs: Additional insights after PRECISION and point of view. Clin. Cardiol. 2017, 40, 1352-1356. [CrossRef]

65. Amaya, F.; Izumi, Y.; Matsuda, M.; Sasaki, M. Tissue injury and related mediators of pain exacerbation. Curr. Neuropharmacol. 2013, 11, 592-597. [CrossRef] [PubMed]

66. Raffa, R.B. Pharmacology of oral combination analgesics: Rational therapy for pain. J. Clin. Pharm. Ther. 2001, 26, 257-264. [CrossRef]

67. Orchard, J.W. Benefits and risks of using local anaesthetic for pain relief to allow early return to play in professional football. Br. J. Sports Med. 2002, 36, 209-213. [CrossRef] [PubMed]

68. Marotta, N.; de Sire, A.; Gimigliano, A.; Demeco, A.; Moggio, L.; Vescio, A.; Iona, T.; Ammendolia, A. Impact of COVID-19 lockdown on the epidemiology of soccer muscle injuries in Italian Serie A professional football players. J. Sports Med. Phys. Fitness. 2021, 21. [CrossRef]

69. Lyrtzis, C.; Natsis, K.; Papadopoulos, C.; Noussios, G.; Papathanasiou, E. Efficacy of paracetamol versus diclofenac for Grade II ankle sprains. Foot Ankle Int. 2011, 32, 571-575. [CrossRef]

70. Paoloni, J.A.; Orchard, J.W. The use of therapeutic medications for soft-tissue injuries in sports medicine. Med. J. Aust. 2005, 183, 384-388. [CrossRef] [PubMed]

71. Jones, P.; Lamdin, R.; Dalziel, S.R. Oral non-steroidal anti-inflammatory drugs versus other oral analgesic agents for acute soft tissue injury. Cochrane Database Syst. Rev. 2020, 8, CD007789. [CrossRef]

72. Orchard, J.W.; Steet, E.; Massey, A.; Dan, S.; Gardiner, B.; Ibrahim, A. Long-term safety of using local anesthetic injections in professional rugby league. Am. J. Sports Med. 2010, 38, 2259-2266. [CrossRef]

73. McDonagh, D.Z.D. The IOC Manual of Emergency Sports Medicine; Wiley-Blackwell: Hoboken, NJ, USA, 2015.

74. Dhillon, S. Tramadol/paracetamol fixed-dose combination: A review of its use in the management of moderate to severe pain. Clin. Drug. Investig. 2010, 30, 711-738. [CrossRef] [PubMed]

75. Veliz, P.T.; Boyd, C.; McCabe, S.E. Playing through pain: Sports participation and nonmedical use of opioid medications among adolescents. Am. J. Public Health 2013, 103, e28-e30. [CrossRef] [PubMed]

76. Babarinde, O.; Ismail, H.; Schellack, N. An overview of the management of muscle pain and injuries. Prof. Nurs. Today 2018, 22, 14-23.

77. Cancer Pain Relief. Available online: http://apps.who.int/iris/bitstream/handle/10665/43944/9241561009_eng.pdf (accessed on 26 August 2021).

78. Sawyer, G.A.; Anderson, B.C.; Raukar, N.P.; Fadale, P.D. Intramuscular ketorolac injections in the athlete. Sports Health 2012, 4, 319-327. [CrossRef] [PubMed] 
79. Huang, S.H.; Johnson, K.; Pipe, A.L. The use of dietary supplements and medications by Canadian athletes at the Atlanta and Sydney Olympic Games. Clin. J. Sport Med. 2006, 16, 27-33. [CrossRef]

80. Derman, E.W.; Schwellnus, M.P. Pain management in sports medicine: Use and abuse of anti-inflammatory and other agents. S. Afr. Fam. Pract. 2010, 52, 27-32.

81. Alaranta, A.; Alaranta, H.; Heliövaara, M.; Airaksinen, M.; Helenius, I. Ample use of physician-prescribed medications in Finnish elite athletes. Int. J. Sports Med. 2006, 27, 919-925. [CrossRef]

82. Warner, D.C.; Schnepf, G.; Barrett, M.S.; Dian, D.; Swigonski, N.L. Prevalence, attitudes, and behaviors related to the use of nonsteroidal anti-inflammatory drugs (NSAIDs) in student athletes. J. Adolesc. Health 2002, 30, 150-153. [CrossRef]

83. Paoloni, J.A.; Milne, C.; Orchard, J.; Hamilton, B. Non-steroidal anti-inflammatory drugs in sports medicine: Guidelines for practical but sensible use. Br. J. Sports Med. 2009, 43, 863-865. [CrossRef]

84. Da Silva, E.R.; De Rose, E.H.; Ribeiro, J.P.; Sampedro, L.B.; Devos, D.V.; Ferreira, A.O.; Kruel, L.F. Non-steroidal anti-inflammatory use in the XV Pan-American Games (2007). Br. J. Sports Med. 2011, 45, 91-94. [CrossRef]

85. Warden, S.J. Prophylactic use of NSAIDs by athletes: A risk/benefit assessment. Phys. Sportsmed. 2010, 38, 132-138. [CrossRef]

86. Lazic, J.S.; Dikic, N.; Radivojevic, N.; Mazic, S.; Radovanovic, D.; Mitrovic, N.; Lazic, M.; Zivanic, S.; Suzic, S. Dietary supplements and medications in elite sport-polypharmacy or real need? Scand. J. Med. Sci. Sports 2011, 21, 260-267. [CrossRef]

87. Tscholl, P.; Junge, A.; Dvorak, J. The use of medication and nutritional supplements during FIFA World Cups 2002 and 2006. Br. J. Sports Med. 2008, 42, 725-730. [CrossRef] [PubMed]

88. Corrigan, B.; Kazlauskas, R. Medication Use in Athletes selected for doping control at the Sydney Olympics (2000). Clin. J. Sport Med. 2003, 13, 33-40. [CrossRef] [PubMed]

89. Anekar, A.A.; Cascella, M. WHO Analgesic Ladder. 2021 May 18. In StatPearls [Internet]; StatPearls Publishing: Treasure Island, FL, USA, 2021.

90. Graham, G.G.; Scott, K.F.; Day, R.O. Tolerability of paracetamol. Drug. Saf. 2005, 28, 227-240. [CrossRef] [PubMed]

91. Toms, L.; Derry, S.; Moore, R.A.; McQuay, H.J. Single dose oral paracetamol (acetaminophen) with codeine for postoperative pain in adults. Cochrane Database Syst. Rev. 2009, 2009, CD001547. [CrossRef]

92. Dalton, J.; Schweinle, J. Randomized controlled noninferiority trial to compare extended release acetaminophen and ibuprofen for the treatment of ankle sprains. Ann. Emerg. Med. 2006, 48, 615-623. [CrossRef]

93. Hyllested, M.; Jones, S.; Pedersen, J.L.; Kehlet, H. Comparative effect of paracetamol, NSAIDs or their combination in postoperative pain management: A qualitative review. Br. J. Anaesth. 2002, 88, 199-214. [CrossRef]

94. Virchenko, O.; Skoglund, B.; Aspenberg, P. Parecoxib impairs early tendon repair but improves later remodelling. Am. J. Sports Med. 2004, 32, 1743-1747. [CrossRef]

95. Cohen, D.B.; Kawamura, S.; Ehteshami, J.R.; Rodeo, S.A. Indomethacin and celecoxib impair rotator cuff tendon-to- bone healing. Am. J. Sports Med. 2006, 34, 362-369. [CrossRef]

96. Alaranta, A.; Alaranta, H.; Helenius, I. Use of prescription drugs in athletes. Sports Med. 2008, 38, 449-463. [CrossRef] [PubMed]

97. Derry, S.; Wiffen, P.J.; Kalso, E.A.; Bell, R.F.; Aldington, D.; Phillips, T.; Gaskell, H.; Moore, R.A. Topical analgesics for acute and chronic pain in adults—an overview of Cochrane Reviews. Cochrane Database Syst. Rev. 2017, 5, CD008609. [CrossRef] [PubMed]

98. Moore, R.A.; Tramer, M.R.; Carroll, D.; Wiffen, P.J.; McQuay, H.J. Quantitative systematic review of topically applied non-steroidal anti-inflammatory drugs. BMJ 1998, 316, 333-338. [CrossRef] [PubMed]

99. De Oliveira, G.S., Jr.; Agarwal, D.; Benzon, H.T. Perioperative single dose ketorolac to prevent postoperative pain: A meta-analysis of randomized trials. Anesth. Analg. 2012, 114, 424-433. [CrossRef]

100. Mehallo, C.J.; Drezner, J.A.; Bytomski, J.R. Practical management: Nonsteroidal antiinflammatory drug (NSAID) use in athletic injuries. Clin. J. Sport Med. 2006, 16, 170-174. [CrossRef]

101. Scorza, K.A.; Cole, W. Current concepts in concussion: Initial evaluation and management. Am. Fam. Physician 2019, 99, 426-434.

102. Dahners, L.E.; Gilbert, J.A.; Lester, G.E.; Taft, T.N.; Payne, L.Z. The effect of a nonsteroidal anti-inflammatory drug on the healing of ligaments. Am. J. Sports Med. 1988, 16, 641-646. [CrossRef]

103. Jarvinen, T.A.H.; Jarvinen, T.L.N.; Kaariainen, M.; Kalimo, H.; Järvinen, M. Muscle injuries biology and treatment. Am. J. Sports Med. 2005, 33, 745-764. [CrossRef]

104. Sharma, P.; Maffulli, N. Tendon injury and tendinopathy: Healing and repair. J. Bone Jt. Surg. 2005, 87, 187-202.

105. Kawaguchi, H.; Pilbeam, C.C.; Harrison, J.R.; Raisz, L.G. The role of prostaglandins in the regulation of bone metabolism. Clin. Orthop. 1995, 313, 36-46.

106. Kanani, A.N.; Hartshorn, S. NICE clinical guideline NG39: Major trauma: Assessment and initial management. Arch. Dis. Child. Educ. Pract. 2017, 102, 20-23. [CrossRef]

107. Vandertuin, J. Athletes, Opioids and the Athletic Therapist; Publications and Scholarship: Mississauga, CA, USA, $2021 ;$ p. 17.

108. Ammendolia, A.; Cespites, M.; Iocco, M. Topical use of aloe gel and low-level laser therapy in overuse tendinitis of elite volleyball players: A randomized controlled trial. Sport Sci. Health 2016, 12, 209-213. [CrossRef]

109. de Sire, A.; Lippi, L.; Curci, C.; Calafiore, D.; Cisari, C.; Ammendolia, A.; Invernizzi, M. Effectiveness of Combined Treatment Using Physical Exercise and Ultrasound-Guided Radiofrequency Ablation of Genicular Nerves in Patients with Knee Osteoarthritis. Appl. Sci. 2021, 11, 4338. [CrossRef]

110. Rodriguez, R.M.; Marroquin, A.; Cosby, N. Reducing Fear of Reinjury and Pain Perception in Athletes With First-Time Anterior Cruciate Ligament Reconstructions by Implementing Imagery Training. J. Sport Rehabil. 2019, 28, 385-389. [CrossRef] [PubMed] 
111. Moore, E.; Thibault, P.; Adams, H.; Sullivan, M. Catastrophizing and pain-related fear predict failure to maintain treatment gains following participation in a pain rehabilitation program. Pain Rep. 2016, 1, e567. [CrossRef]

112. de Sire, A.; Invernizzi, M. Musculoskeletal Rehabilitation: State-of-the-Art. Appl. Sci. 2021, 11, 6243. [CrossRef]

113. Bayer, M.L.; Hoegberget-Kalisz, M.; Jensen, M.H.; Olesen, J.L.; Svensson, R.B.; Couppé, C.; Boesen, M.; Nybing, J.D.; Kurt, E.Y.; Magnusson, S.P.; et al. Role of tissue perfusion, muscle strength recovery, and pain in rehabilitation after acute muscle strain injury: A randomized controlled trial comparing early and delayed rehabilitation. Scand. J. Med. Sci. Sports 2018, 28, 2579-2591. [CrossRef]

114. Wakabayashi, H. Rehabilitation pharmacotherapy: A combination of rehabilitation and pharmacotherapy. J. Gen. Fam. Med. 2018, 19, 43-44. [CrossRef]

115. Kose, E.; Wakabayashi, H. Rehabilitation pharmacotherapy: A scoping review. Geriatr. Gerontol. Int. 2020, 20, 655-663. [CrossRef]

116. de Sire, A.; Agostini, F.; Lippi, L.; Mangone, M.; Marchese, S.; Cisari, C.; Bernetti, A.; Invernizzi, M. Oxygen-Ozone Therapy in the Rehabilitation Field: State of the Art on Mechanisms of Action, Safety and Effectiveness in Patients with Musculoskeletal Disorders. Biomolecules 2021, 11, 356. [CrossRef]

117. de Sire, A.; Stagno, D.; Minetto, M.A.; Cisari, C.; Baricich, A.; Invernizzi, M. Long-term effects of intra-articular oxygen-ozone therapy versus hyaluronic acid in older people affected by knee osteoarthritis: A randomized single-blind extension study. J. Back Musculoskelet. Rehabil. 2020, 33, 347-354. [CrossRef]

118. de Sire, A.; Ammendolia, A.; Lippi, L.; Farì, G.; Cisari, C.; Invernizzi, M. Percutaneous Electrical Nerve Stimulation (PENS) as a Rehabilitation Approach for Reducing Mixed Chronic Pain in Patients with Musculoskeletal Disorders. Appl. Sci. 2021, 11, 4257. [CrossRef]

119. Orchard, J.W. Is it safe to use local anaesthetic painkilling injections in professional football? Sports Med. 2004, 34, 209-219. [CrossRef]

120. Sebak, S.; Orchard, J.W.; Golding, L.D.; Steet, E.; Brennan, S.A.; Ibrahim, A. Long-Term Safety of Using Local Anesthetic Injections in Professional Rugby League for Modified Indications. Clin. J. Sport Med. 2018, 28, 435-442. [CrossRef]

121. Drakos, M.; Birmingham, P.; Delos, D.; Barnes, R.; Murphy, C.; Weiss, L.; Warren, R. Corticosteroid and anesthetic injections for muscle strains and ligament sprains in the NFL. HSS J. 2014, 10, 136-142. [CrossRef]

122. Olafsen, N.P.; Herring, S.A. Pain management in sport: Therapeutic injections. Handb. Clin. Neurol. 2018, 158, 431-442. [CrossRef]

123. Dietzel, D.P.; Hedlund, E.C. Injections and return to play. Curr. Sports Med. Rep. 2004, 3, 310-315. [CrossRef] [PubMed]

124. Nepple, J.J.; Matava, M.J. Soft tissue injections in the athlete. Sports Health 2009, 1, 396-404. [CrossRef] [PubMed]

125. Nichols, A.W. Complications associated with the use of corticosteroids in the treatment of athletic injuries. Clin. J. Sport Med. 2005, 15, 370-375. [CrossRef] [PubMed]

126. Buchbinder, R.; Green, S.; Youd, J.M. Corticosteroid injections for shoulder pain. Cochrane Database Syst. Rev. 2003, 2003, CD004016. [CrossRef]

127. Arroll, B.; Goodyear-Smith, F. Corticosteroid injections for painful shoulder: A meta-analysis. Br. J. Gen. Pract. 2005, 55, 224-228. [PubMed]

128. Coombes, B.K.; Bisset, L.; Vicenzino, B. Efficacy and safety of corticosteroid injections and other injections for management of tendinopathy: A systematic review of randomised controlled trials. Lancet 2010, 376, 1751-1767. [CrossRef]

129. Gross, C.; Dhawan, A.; Harwood, D.; Gochanour, E.; Romeo, A. Glenohumeral joint injections: A review. Sports Health 2013, 5 , 153-159. [CrossRef] [PubMed]

130. Smith, B.J.; Collina, S.J. Pain medications in the locker room: To dispense or not. Curr. Sports Med. Rep. 2007, 6, 367-370. [CrossRef]

131. Hall-Burton, D.M.; Hudson, M.E.; Grudziak, J.S.; Cunningham, S.; Boretsky, K.R. Regional anesthesia is cost-effective in preventing unanticipated hospital admission in pediatric patients having anterior cruciate ligament reconstruction. Reg. Anesth. Pain Med. 2016, 41, 527-531. [CrossRef]

132. Dadure, C.; Bringuier, S.; Raux, O.; Rochette, A.; Troncin, R.; Canaud, N.; Lubrano-Lavadera, J.F.; Capdevila, X. Continuous peripheral nerve blocks for postoperative analgesia in children: Feasibility and side effects in a cohort study of 339 catheters. Can. J. Anaesth. 2009, 56, 843-850. [CrossRef]

133. Crimaldi, S.; Liguori, S.; Tamburrino, P.; Moretti, A.; Paoletta, M.; Toro, G.; Iolascon, G. The Role of Hyaluronic Acid in Sport-Related Tendinopathies: A Narrative Review. Medicina 2021, 57, 1088. [CrossRef] [PubMed]

134. Bannuru, R.R.; Osani, M.C.; Vaysbrot, E.E.; Arden, N.K.; Bennell, K.; Bierma-Zeinstra, S.M.A.; Kraus, V.B.; Lohmander, L.S.; Abbott, J.H.; Bhandari, M.; et al. OARSI guidelines for the non-surgical management of knee, hip, and polyarticular osteoarthritis. Osteoarthr. Cartil. 2019, 27, 1578-1589. [CrossRef]

135. da Costa, S.R.; e Albuquerque, R.F.d.M.; Helito, C.P.; Camanho, G.L. The role of viscosupplementation in patellar chondropathy. Ther. Adv. Musculoskelet. Dis. 2021, 13, 1759720X211015005. [CrossRef]

136. Vernec, A.; Slack, A.; Harcourt, P.R.; Budgett, R.; Duclos, M.; Kinahan, A.; Mjøsund, K.; Strasburger, C.J. Glucocorticoids in elite sport: Current status, controversies and innovative management strategies-a narrative review. Br. J. Sports Med. 2020, 54, 8-12. [CrossRef]

137. Kii, N.; Yamauchi, M.; Takahashi, K.; Yamakage, M.; Wada, T. Differential axillary nerve block for hand or forearm soft-tissue sur-gery. J. Anesth. 2014, 28, 549-553. [CrossRef] [PubMed] 
138. Brattwall, M.; Jildenstål, P.; Stomberg, M.W.; Jakobsson, J.G. Upper extremity nerve block: How can benefit, duration, and safety be improved? An update. F1000Research 2016, 5, F1000. [CrossRef] [PubMed]

139. Chen, J.Y.; Li, N.; Xu, Y.Q. Single Shot Adductor Canal Block for Postoperative Analgesia of Pediatric Patellar Dislocation Surgery: A Case-Series Report. Medicine 2015, 94, e2217. [CrossRef] [PubMed]

140. Wathen, J.E.; Gao, D.; Merritt, G.; Georgopoulos, G.; Battan, F.K. A randomized controlled trial comparing a fascia iliaca compartment nerve block to a traditional systemic analgesic for femur fractures in a pediatric emergency department. Ann. Emerg. Med. 2007, 50, 162-171.e1. [CrossRef] [PubMed]

141. Elsey, N.M.; Tobias, J.D.; Klingele, K.E.; Beltran, R.J.; Bhalla, T.; Martin, D.; Veneziano, G.; Rice, J.; Tumin, D. A prospective, double-blinded, randomized comparison of ultrasound-guided femoral nerve block with lateral femoral cutaneous nerve block versus standard anesthetic management for pain control during and after traumatic femur fracture repair in the pediatric population. J. Pain Res. 2017, 10, 2177-2182. [CrossRef]

142. Farid, I.S.; Heiner, E.J.; Fleissner, P.R. Comparison of femoral nerve block and fascia iliaca block for analgesia following reconstructive knee surgery in adolescents. J. Clin. Anesth. 2010, 22, 256-259. [CrossRef]

143. Gazendam, A.; Ekhtiari, S.; Horner, N.S.; Nucci, N.; Dookie, J.; Ayeni, O.R. Perioperative nonopioid analgesia reduces postoperative opioid consumption in knee arthroscopy: A systematic review and meta-analysis. Knee Surg. Sports Traumatol. Arthrosc. 2021, 29, 1887-1903. [CrossRef]

144. Elmallah, R.K.; Cherian, J.J.; Pierce, T.P.; Jauregui, J.J.; Harwin, S.F.; Mont, M.A. New and Common Perioperative Pain Management Techniques in Total Knee Arthroplasty. J. Knee Surg. 2016, 29, 169-178. [CrossRef]

145. Morrison, R.S.; Dickman, E.; Hwang, U.; Akhtar, S.; Ferguson, T.; Huang, J.; Jeng, C.L.; Nelson, B.P.; Rosenblatt, M.A.; Silverstein, J.H.; et al. Regional Nerve Blocks Improve Pain and Functional Outcomes in Hip Fracture: A Randomized Controlled Trial. J. Am. Geriatr. Soc. 2016, 64, 2433-2439. [CrossRef]

146. Hsu, J.R.; Mir, H.; Wally, M.K.; Seymour, R.B.; Orthopaedic Trauma Association Musculoskeletal Pain Task Force. Clinical Practice Guidelines for Pain Management in Acute Musculoskeletal Injury. J. Orthop. Trauma 2019, 33, e158-e182. [CrossRef]

147. Saccomanno, M.F.; Donati, F.; Careri, S.; Bartoli, M.; Severini, G.; Milano, G. Efficacy of intra-articular hyaluronic acid injections and exercise-based rehabilitation programme, administered as isolated or integrated therapeutic regimens for the treatment of knee osteoarthritis. Knee Surg. Sports Traumatol. Arthrosc. 2016, 24, 1686-1694. [CrossRef]

148. Bement, M.K.H.; Sluka, K.A. Exercise-induced hypoalgesia: An Evidence-based review. In Mechanisms and Management for the Physical Therapist; Sluka, K.A., Ed.; Wolters Kluwer: Philadelphia, PA, USA, 2016; pp. 177-202.

149. Elfving, B.; Andersson, T.; Grooten, W.J. Low levels of physical activity in back pain patients are associated with high levels of fear-avoidance beliefs and pain catastrophizing. Physiother. Res. Int. 2007, 12, 14-24. [CrossRef]

150. Bagwell, M.S.; Wilk, K.E.; Colberg, R.E.; Dugas, J.R. The use of serial platelet rich plasma injections with early rehabilitation to expedite grade iii medial collateral ligament injury in a professional athlete: A case report. Int. J. Sports Phys. Ther. 2018, 13, 520-525. [CrossRef] [PubMed]

151. Brooks, G.; Almquist, J. Rehabilitation of Musculoskeletal Injuries in Young Athletes. Adolesc. Med. State Art Rev. 2015, 26, 100-115. [PubMed]

152. Daniels, K.; King, E.; Richter, C.; Falvey, É; Franklyn-Miller, A. Changes in the kinetics and kinematics of a reactive cut maneuver after successful athletic groin pain rehabilitation. Scand. J. Med. Sci. Sports 2021, 31, 839-847. [CrossRef]

153. Hart, H.F.; Culvenor, A.G.; Guermazi, A.; Crossley, K.M. Worse knee confidence, fear of movement, psychological readiness to return-to-sport and pain are associated with worse function after ACL reconstruction. Phys. Ther. Sport 2020, 41, 1-8. [CrossRef] [PubMed]

154. Chimenti, R.L.; Frey-Law, L.A.; Sluka, K.A. A Mechanism-Based Approach to Physical Therapist Management of Pain. Phys. Ther 2018, 98, 302-314. [CrossRef]

155. Sluka, K.A.; Frey-Law, L.; Bement, M.H. Exercise-induced pain and analgesia? Underlying mechanisms and clinical translation. Pain 2018, 159 (Suppl. 1), S91-S97. [CrossRef]

156. Buckthorpe, M. Optimising the Late-Stage Rehabilitation and Return-to-Sport Training and Testing Process After ACL Reconstruction. Sports Med. 2019, 49, 1043-1058. [CrossRef]

157. Buckthorpe, M.; Villa, F.D.; Villa, S.D.; Roi, G.S. On-field Rehabilitation Part 1: 4 Pillars of High-Quality On-field Rehabilitation Are Restoring Movement Quality, Physical Conditioning, Restoring Sport-Specific Skills, and Progressively Developing Chronic Training Load. J. Orthop. Sports Phys. Ther. 2019, 49, 565-569. [CrossRef]

158. Harmon, K.G.; Clugston, J.R.; Dec, K.; Hainline, B.; Herring, S.A.; Kane, S.; Kontos, A.P.; Leddy, J.J.; McCrea, M.A.; Poddar, S.K.; et al. American Medical Society for Sports Medicine Position Statement on Concussion in Sport. Clin. J. Sport Med. 2019, 29, 87-100. [CrossRef]

159. Ekstrand, J.; Krutsch, W.; Spreco, A.; Van Zoest, W.; Roberts, C.; Meyer, T.; Bengtsson, H. Time before return to play for the most common injuries in professional football: A 16-year follow-up of the UEFA Elite Club Injury Study. Br. J. Sports Med. 2020, 54, 421-426. [CrossRef]

160. Dijkstra, H.P.; Pollock, N.; Chakraverty, R.; Ardern, C.L. Return to play in elite sport: A shared decision-making process. Br. J. Sports Med. 2017, 51, 419-420. [CrossRef] 
161. Tassignon, B.; Verschueren, J.; Delahunt, E.; Smith, M.; Vicenzino, B.; Verhagen, E.; Meeusen, R. Criteria-Based Return to Sport Decision-Making Following Lateral Ankle Sprain Injury: A Systematic Review and Narrative Synthesis. Sports Med. 2019, 49, 601-619. [CrossRef] [PubMed]

162. Wikstrom, E.A.; Mueller, C.; Cain, M.S. Lack of Consensus on Return-to-Sport Criteria Following Lateral Ankle Sprain: A Systematic Review of Expert Opinions. J. Sport Rehabil. 2020, 29, 231-237. [CrossRef] [PubMed]

163. Barber-Westin, S.; Noyes, F.R. One in 5 Athletes Sustain Reinjury Upon Return to High-Risk Sports After ACL Reconstruction: A Systematic Review in 1239 Athletes Younger Than 20 Years. Sports Health 2020, 12, 587-597. [CrossRef] [PubMed]

164. Shelbourne, K.D.; Benner, R.W.; Gray, T. Return to Sports and Subsequent Injury Rates After Revision Anterior Cruciate Ligament Reconstruction With Patellar Tendon Autograft. Am. J. Sports Med. 2014, 42, 1395-1400. [CrossRef] [PubMed]

165. Wright, A.R.; Richardson, A.B.; Kikuchi, C.K.; Goldberg, D.B.; Marumoto, J.M.; Kan, D.M. Effectiveness of Accelerated Recovery Performance for Post-ACL Reconstruction Rehabilitation. Hawai'i J. Health Soc. Welf. 2019, 78 (Suppl. 2), 41-46.

166. Kim, C.; Chasse, P.M.; Taylor, D.C. Return to Play After Medial Collateral Ligament Injury. Clin. Sports Med. 2016, 35, 679-696. [CrossRef]

167. Ardern, C.L.; Glasgow, P.; Schneiders, A.G.; Witvrouw, E.; Clarsen, B.; Cools, A.M.; Gojanovic, B.; Griffin, S.; Khan, K.; Moksnes, H.; et al. Infographic: 2016 Consensus statement on return to sport from the First World Congress in Sports Physical Therapy, Bern. Br. J. Sports Med. 2017, 51, 995. [CrossRef]

168. Danielsson, A.; Horvath, A.; Senorski, C.; Alentorn-Geli, E.; Garrett, W.E.; Cugat, R.; Samuelsson, K.; Senorski, E.H. The mechanism of hamstring injuries - a systematic review. BMC Musculoskelet. Disord. 2020, 21, 641. [CrossRef]

169. Gimigliano, F.; Resmini, G.; Moretti, A.; Aulicino, M.; Gargiulo, F.; Gimigliano, A.; Liguori, S.; Paoletta, M.; Iolascon, G. Epidemiology of Musculoskeletal Injuries in Adult Athletes: A Scoping Review. Medicina 2021, 57, 1118. [CrossRef] [PubMed]

170. Askling, C.M.; Tengvar, M.; Saartok, T.; Thorstensson, A. Acute first-time hamstring strains during high-speed running: A longitudinal study including clinical and magnetic resonance imaging findings. Am. J. Sports Med. 2007, 35, 197-206.

171. Vatovec, R.; Kozinc, Ž.; Šarabon, N. Exercise interventions to prevent hamstring injuries in athletes: A systematic review and meta-analysis. Eur. J. Sport Sci. 2020, 20, 992-1004. [CrossRef] [PubMed]

172. Moen, M.H.; Reurink, G.; Weir, A.; Tol, J.L.; Maas, M.; Goudswaard, G.J. Predicting return to play after hamstring injuries. Br. J. Sports Med. 2014, 48, 1358-1363. [CrossRef]

173. Reurink, G.; Brilman, E.G.; de Vos, R.J.; Maas, M.; Moen, M.H.; Weir, A.; Goudswaard, G.J.; Tol, J.L. Magnetic resonance imaging in acute hamstring injury: Can we provide a return to play prognosis? Sports Med. 2015, 45, 133-146. [CrossRef] [PubMed]

174. Chu, S.K.; Rho, M.E. Hamstring Injuries in the Athlete: Diagnosis, Treatment, and Return to Play. Curr. Sports Med. Rep. 2016, 15, 184-190. [CrossRef]

175. Tarantino, D.; Palermi, S.; Sirico, F.; Corrado, B. Achilles Tendon Rupture: Mechanisms of Injury, Principles of Rehabilitation and Return to Play. J. Funct. Morphol. Kinesiol. 2020, 5, 95. [CrossRef]

176. Silbernagel, K.G.; Hanlon, S.; Sprague, A. Current Clinical Concepts: Conservative Management of Achilles Tendinopathy. J. Athl. Train. 2020, 55, 438-447. [CrossRef]

177. Brorsson, A.; Silbernagel, K.G.; Olsson, N.; Helander, K.N. Calf Muscle Performance Deficits Remain 7 Years After an Achilles Tendon Rupture. Am. J. Sports Med. 2018, 46, 470-477. [CrossRef]

178. Saxena, A.; Maffulli, N.; Jin, A.; Isa, E.; Arthur, W.P.; Asthana, S. Acute Achilles Tendon Rupture Repair in Athletically Active Patients: Results on 188 Tendons. J. Foot Ankle Surg. 2021, 60, 935-940. [CrossRef] [PubMed]

179. Lu, Y.; Okoroha, K.R.; Patel, B.H.; Nwachukwu, B.U.; Baker, J.D.; Idarraga, A.J.; Forsythe, B. Return to play and performance after shoulder instability in National Basketball Association athletes. J. Shoulder Elb. Surg. 2020, 29, 50-57. [CrossRef]

180. Nelson, S.Y.; LeClere, L.E. Management of the First-Time Shoulder Dislocation. Oper. Tech. Orthop. 2020, 30, 100817. [CrossRef]

181. Ialenti, M.N.; Mulvihill, J.D.; Feinstein, M.; Zhang, A.L.; Feeley, B.T. Return to Play Following Shoulder Stabilization: A Systematic Review and Meta-analysis. Orthop. J. Sports Med. 2017, 5, 2325967117726055. [CrossRef]

182. Riccio, I.; de Sire, A.; Latte, C.; Pascarella, F.; Gimigliano, F. Conservative treatment of traumatic shoulder instability: A case series study. Musculoskelet. Surg. 2015, 99, 133-137. [CrossRef]

183. Rosenthal, B.D.; Boody, B.S.; Hsu, W.K. Return to Play for Athletes. Neurosurg. Clin. N. Am. 2017, 28, 163-171. [CrossRef]

184. Huang, P.; Anissipour, A.; McGee, W.; Lemak, L. Return-to-Play Recommendations After Cervical, Thoracic, and Lumbar Spine Injuries: A Comprehensive Review. Sports Health 2016, 8, 19-25. [CrossRef]

185. Vernec, A.; Pipe, A.; Slack, A. A painful dilemma? Analgesic use in sport and the role of anti-doping. Br. J. Sports Med. 2017, 51, 1243-1244. [CrossRef]

186. World Anti-Doping Agency. List of Prohibited Substances and Methods. 2021. Available online: Chrome-extension: / / efaidnbmnnnibpcajpcglclefindmkaj/viewer.html?pdfurl=https $\% 3 \mathrm{~A} \% 2 \mathrm{~F} \% 2 \mathrm{Fwww} . w a d a-a m a . o r g \% 2 F s i t e s \% 2 F d e f a u l t \%$ 2Ffiles\%2Fresources\%2Ffiles\%2F2021list_en.pdf\&clen=2817486\&chunk=true (accessed on 12 September 2021).

187. de Sire, A.; Marotta, N.; Demeco, A.; Moggio, L.; Paola, P.; Marotta, M.; Iona, T.; Invernizzi, M.; Leigheb, M.; Ammendolia, A. Electromyographic Assessment of Anterior Cruciate Ligament Injury Risk in Male Tennis Players: Which Role for Visual Input? A Proof-of-Concept Study. Diagnostics 2021, 11, 997. [CrossRef] [PubMed]

188. Marotta, N.; Demeco, A.; Moggio, L.; Isabello, L.; Iona, T.; Ammendolia, A. Correlation between dynamic knee valgus and quadriceps activation time in female athletes. J. Phys. Educ. Sport 2020, 20, 2508-2512. 
189. Holgado, D.; Hopker, J.; Sanabria, D.; Zabala, M. Analgesics and Sport Performance: Beyond the Pain-Modulating Effects. PMR 2018, 10, 72-82. [CrossRef]

190. Ekhtiari, S.; Yusuf, I.; AlMakadma, Y.; MacDonald, A.; Leroux, T.; Khan, M. Opioid Use in Athletes: A Systematic Review. Sports Health 2020, 12, 534-539. [CrossRef] [PubMed]

191. Baltazar-Martins, J.G.; Plata, M.; Muñoz-Guerra, J.; Muñoz, G.; Carreras, D.; Del Coso, J. Infographic. Tramadol: Should it be banned in athletes while competing, particularly in road cycling? Br. J. Sports Med. 2020, 54, 120-121. [CrossRef] [PubMed]

192. Hagiu, B.A.; Mungiu, O.C. Negative Resonances of Antialgic Medication in Athletes. Ann. Dunarea Jos Univ. Galati. Fascicle XV Phys. Educ. Sport Manag. 2018, 1, 41-43. [CrossRef]

193. Nielsen, R.O.; Shrier, I.; Casals, M.; Nettel-Aguirre, A.; Møller, M.; Bolling, C.; Bittencourt, N.; Clarsen, B.; Wedderkopp, N.; Soligard, T.; et al. Statement on methods in sport injury research from the 1st methods matter meeting, Copenhagen, $2019 . \mathrm{Br}$. J. Sports Med. 2020, 54, 941. [CrossRef] [PubMed] 